\title{
Comparison of Revised Trauma Score, Injury Severity Score and Trauma and Injury Severity Score for mortality prediction in elderly trauma patients
}

\author{
Shahrokh Yousefzadeh-Chabok, M.D., ${ }^{1,2}$ Marieh Hosseinpour, M.D., ${ }^{1}$ Leila Kouchakinejad-Eramsadati, M.D., ${ }^{1}$ \\ Fatemeh Ranjbar, M.D., ${ }^{2}$ Reza Malekpouri, M.D., ${ }^{1}$ Alireza Razzaghi, M.D., ${ }^{1}$ Zahra Mohtasham-Amiri, M.D. ${ }^{1,3}$
}

${ }^{1}$ Guilan Road Trauma Research Center, Guilan University of Medical Sciences, Rasht-Iran
${ }^{2}$ Department of Neurosurgery, Guilan University of Medical Sciences, Rasht-Iran
${ }^{3}$ Department of Social and Preventive Medicine, Guilan University of Medical Sciences, Rasht-Iran

ABSTRACT

BACKGROUND: Trauma is the fifth leading cause of death in patients 65 years and older. This study is a comparison of results of Revised Trauma Score (RTS), Injury Severity Score (ISS), and Trauma and Injury Severity Score (TRISS) in prediction of mortality in cases of geriatric trauma.

METHODS: This is a cross-sectional study of records of 352 elderly trauma patients who were admitted to Pour-Sina Hospital in Rasht between 2010 and $201 \mathrm{I}$. Injury scoring systems were compared in terms of specificity, sensitivity, and cut-off points using receiver operating characteristic curve of patient prognosis.

RESULTS: Mean age of patients was 71.5 years. Most common mechanism of injury was traffic accident (53.7\%). Of the total, I3.9\% of patients died. Mean ISS was higher for patients who did not survive. Mean of TRISS and RTS scores in elderly survivors was higher than non-survivors and difference in all 3 scores was statistically significant $(p<0.001)$. Best cut-off points for predicting mortality in elderly trauma patients in RTS, ISS, and TRISS systems were $\leq 6, \geq 13.5$, and $\leq 2$, with sensitivity of $99 \%, 84 \%$, and $95 \%$ and specificity of $62 \%, 62 \%$, and $72 \%$, respectively.

CONCLUSION: TRISS was the strongest predictor of mortality in elderly trauma patients as result of combination of both anatomical and physiological parameters.

Keywords: Geriatric, ROC curve; scoring; trauma.

\section{INTRODUCTION}

The world population is aging. ${ }^{[1]}$ It is expected that the elderly population will double and triple in developed and developing countries by 2050 , respectively. ${ }^{[2]}$ Geriatric trauma is a significant issue for healthcare systems, as the size of elderly population is already growing. ${ }^{[3-5]}$ Secondly, greater activity and mobility in their lifestyle puts them at serious risk, ${ }^{[3,6]}$

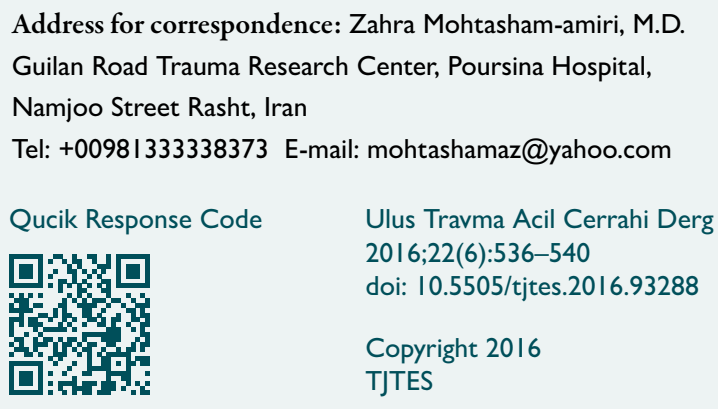

and thirdly, post-trauma outcomes have shown that results of injury are substantially worse for the elderly than for younger patients. ${ }^{[3,7,8]}$ According to previous studies, trauma accounts for about $28 \%$ of mortality in geriatric patients, while mortality rate has been estimated at $12 \%$ of total trauma population. ${ }^{[9]}$ The phenomenon of population aging has started in Iran, too. Although the population is still relatively young, it is predicted that the elderly population will double in less than 20 years. ${ }^{[10]}$ Trauma is the fifth leading cause of death in people 65 years and older. ${ }^{[7,9,11]}$ Elderly trauma patients are hospitalized for a longer period, pay higher hospital costs, and often require an extended period of rehabilitation. These patients also have higher rates of post-trauma complications that contribute to worse outcomes. ${ }^{[9]}$ However, outcomes of major trauma can be minimized through pre-hospital admission measures. ${ }^{[12,13]}$ To study the outcomes of trauma, accurate and reliable methodological tools are required for appropriate scoring of severity and outcome prediction. ${ }^{[14-18]}$ Statistical scores for predicting outcomes can be divided into 
3 categories: anatomical scores, physiological scores, or a combination of the 2. ${ }^{[18]}$ Trauma and Injury Severity Score (TRISS), Revised Trauma Score (RTS), and Injury Severity Score (ISS) are scoring systems used to assist in clinical decision-making and to aid physicians in initial evaluation of trauma. ISS is an anatomical score and independent predictor of death that is mostly used for patients with multiple injuries. ${ }^{[19]}$ RTS is a physiological score for predicting in-hospital mortality and outcome of traumatic patients. ${ }^{[20]}$ TRISS uses a combination of both physiological and anatomical injury severity scores (ISS and RTS) as well as patient age to predict post-trauma survival. ${ }^{[16]}$ Trauma scoring systems are key indicators used to identify adverse outcomes within first hours of admission and predict outcomes of elderly patients.

This study examined outcomes of trauma and relationship to ISS, RTS, and TRISS scores with underlying variables such as morbidity and mortality rates. This study was an effort to identify the best scoring system to apply for prompt and appropriate therapeutic approach with geriatric patients.

\section{MATERIALS AND METHODS}

This is a cross-sectional study conducted on 352 elderly trauma patients who were admitted to emergency ward of Pour-Sina Hospital of Rasht (Guilan Province, Iran) between 2010 and 201 I. Data collection tool was a checklist, which included demographic information, site, and type of injury, initial assessment of patient (vital signs), and scoring tables for calculation of ISS, RTS, and TRISS. To calculate ISS, 3 most injured organs were evaluated. Square values of 3 highest Abbreviated Injury Scale scores in different areas of body were used. RTS is calculated based on Glasgow Coma Scale, systolic blood pressure, and respiratory rate, according to effect coefficient determined by logistic regression model. TRISS is obtained based on physiological and anatomical status of patient on admission and patient age according to the following formula: $\beta_{i}=\beta_{1}+\beta_{2}$ (RTS) $+\beta_{3}($ ISS $)+\beta_{4}$ (AGE), where $\beta \mathrm{i}$ is regression coefficient. In this score, probability of patient survival (Ps) is calculated using logistic function $p_{s}>\frac{1}{(1, e)}$. To compare ISS, RTS, and TRISS in terms of mortality prediction accuracy, Kolmogorov-Smirnov test was used to examine normality distribution. Mann-Whitney test was employed to compare distribution of values for ISS, RTS, and TRISS in survivors and nonsurvivors. Finally, they were compared in terms of specificity, sensitivity, and cut-off points based on receiver operating characteristic curve (ROC) associated with prognosis of patients using SPSS software (version I8; SPSS Inc., Chicago, IL, USA).

\section{RESULTS}

This study was conducted using records of 352 elderly trauma patients. Of the total, $46.6 \%$ were women $(n=164)$ and $53.4 \%$ were men $(n=188)$. Mean age of patients was $71.55 \pm 8.07$ years (range: 60-100 years). Mean age of female and male patients was 72.7 years $( \pm 8.24$ years $)$ and 70.55 years $( \pm 7.79$ years), respectively. Most common mechanism of trauma was road traffic accident (53.7\%), followed by fall (41.5\%). Overall, $96.6 \%(n=340)$ and $3.4 \%(n=12)$ of total trauma cases were blunt and penetrating, respectively. Most common injured organs were upper and lower extremities (93.5\%; $n=329)$, followed by head and neck $(37.8 \%$; $=133)$ (Figure I).

Of total 352 patients, 303 patients $(86.1 \%)$ recovered after treatment in hospital and 49 patients (13.9\%) died.

Results indicated that all 3 indices followed a normal distribution $(p>0.05)$ in non-survivor group, while distribution of survivors was not normal $(p<0.001)$.

Numerical values were used to calculate mean and comparison between survivors and non-survivors. Mean ISS, RTS, and TRISS

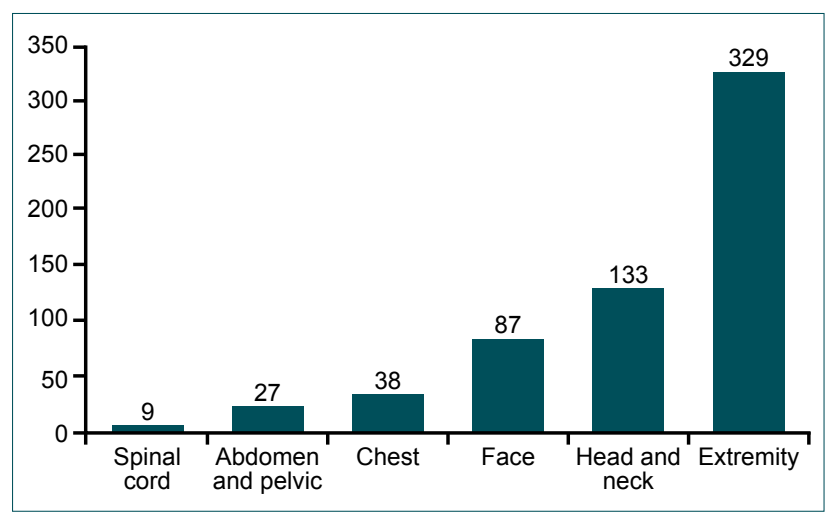

Figure 1. Frequency of injuries in different organs of trauma patients

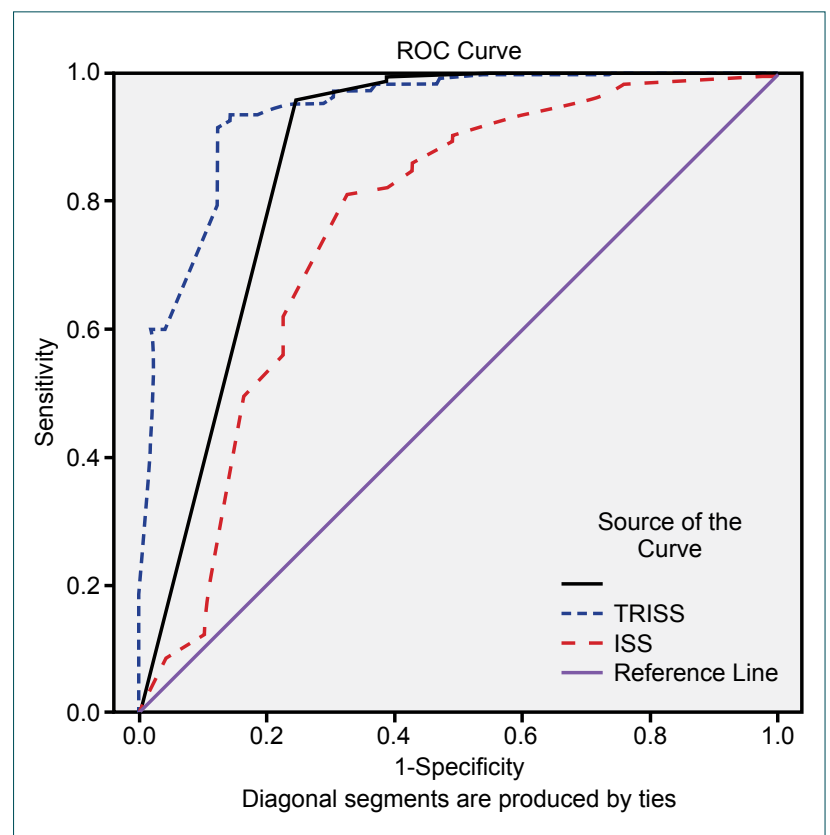

Figure 2. ROC curve of ISS, RTS, and TRISS in mortality prediction of elderly trauma patients. ISS: Injury Severity Score; ROC: Receiver operating characteristic RTS: Revised Trauma Score; TRISS: Trauma and Injury Severity Score. 
Table I. Mean ISS, RTS, and TRISS of elderly survivors and non-survivors

\begin{tabular}{|c|c|c|c|}
\hline \multirow[t]{2}{*}{ Index } & $\begin{array}{l}\text { Survivors } \\
(n=49)\end{array}$ & $\begin{array}{c}\text { Non-survivors } \\
\quad(n=303)\end{array}$ & $\mathbf{p}$ \\
\hline & Mean \pm SD & Mean $\pm S D$ & \\
\hline Injury Severity Score & $15.95 \pm 10.46$ & $7.31 \pm 6.22$ & 0.000 \\
\hline Revised Trauma Score & $5.65 \pm 1.82$ & $7.79 \pm 0.27$ & 0.000 \\
\hline Trauma and Injury Severity Score & $1.04 \pm 1.49$ & $3.49 \pm 0.60$ & 0.000 \\
\hline
\end{tabular}

SD: Standard deviation.

Table 2. Comparison of area under ROC curve for trauma scoring systems

\begin{tabular}{lccc}
\hline Index & Area under the Curve* & Cl: 95\% & p \\
\hline Injury Severity Score & 0.76 & $0.68-0.85$ & 0.000 \\
Revised Trauma Score & 0.87 & $0.79-0.94$ & 0.000 \\
Trauma and Injury Severity Score & 0.94 & $0.90-0.98$ & 0.000 \\
\hline *: Statistically significant for all three scores. & & &
\end{tabular}

Table 3. Comparison of sensitivity, specificity, positive likelihood ratio and negative likelihood ratio of optimum cut-off points based on ROC in ISS, RTS and TRISS

\begin{tabular}{lccccc}
\hline & -LR $^{* *}$ & $\mathbf{L R}^{*}$ & Specificity (\%) & Sensitivity (\%) & Cut-off \\
\hline ISS & 0.24 & 2.04 & 58 & 86 & $\leq 12.5$ \\
RTS & 0.02 & 2.60 & 62 & 99 & $\geq 6$ \\
TRISS & 0.07 & 3.39 & 72 & 95 & $\geq 2$ \\
\hline
\end{tabular}

"+LR: Positive likelihood ratio= sensitivity/I-specificity; " ${ }^{*}$-LR: Negative likelihood ratio= I-sensitivity/specificity. ISS: Injury Severity Score; ROC: Receiver operating characteristic RTS: Revised Trauma Score; TRISS: Trauma and Injury Severity Score.

of both survivors and non-survivors are presented in Table I.

As can be seen in Table I, mean ISS was higher for non-surviving elderly patients than survivors. It was determined that means of TRISS and RTS were higher for survivors than nonsurviving patients. Difference in mean was statistically significant in all 3 scores $(p<0.00 I)$. TRISS $(94 \%)$ and ISS (76\%) had the highest and lowest area under ROC for prediction of mortality. Area under ROC curve for all 3 scores was statistically significant (Table 2 and Figure 2).

The best cut-off point for predicting mortality in elderly patients was $\leq 6$ for RTS with sensitivity of $99 \%$ and specificity of $62 \%$, while for ISS it was determined to be $\geq 13.5$ with $84 \%$ sensitivity and $62 \%$ specificity, and for TRISS it was $\leq 2$ with $95 \%$ sensitivity and $72 \%$ specificity (Table 3 ).

\section{DISCUSSION}

Most of 352 elderly trauma patients in the present study were men. Some studies have had similar results, ${ }^{[21-23]}$ while other studies reported that more geriatric trauma patients were women. ${ }^{[24,25]}$ Mean age of our patients was 71.5 years with age range of 60 to 100 years. This is consistent with other studies. ${ }^{[4,26,27]}$ The present study indicated that the most common mechanisms leading to trauma in the elderly were motor vehicle accidents, followed by falls. A study by Akköse Aydin et al. also revealed that most common mechanism leading to trauma was motor vehicle accident, ${ }^{[22]}$ while in a study conducted by Richmond et al. it was found that $61.7 \%$ of injuries in the elderly occurred due to fall. ${ }^{[26]}$ Moreover, study by Bradburn et al. indicated that the most frequent mechanism was fall followed by road traffic accidents. [24] Present study was conducted at Pour-Sina Hospital, in northern Iran, which has the highest accident referral rate in this region of country and this may have influenced finding about incidence of accidents. Most frequently injured organ was extremity, followed by head and neck. In their research, Akköse Aydin et al. reported that the most common injury sites were head and extremities. ${ }^{[22]}$ In this study, $13.9 \%$ of 
elderly trauma patients died. Parreira et al. found that $5 \%$ of the patients in $70-79$ age group and $5.3 \%$ of patients aged over 80 years died. ${ }^{[4]}$ Kim's study reported mortality rate of $18.1 \%{ }^{[27]}$ In the present study, mean plus standard deviation of ISS for non-survivors was $15.95 \pm 10.46$ and $7.31 \pm 6.22$ for survivors; mean plus standard deviation of RTS for former was $5.65 \pm 1.82$, and $7.79 \pm 0.27$ for latter group. Mean plus standard deviation of TRISS for non-survivors was I.04 \pm 1.49 and was $3.49 \pm 0.6$ for survivors. In research conducted by Akköse Aydin et al., mean of RTS was 11.6 and 8.3 in survivors and non-survivors, while mean of ISS was 8 in survivors and 20 in non-survivors. ${ }^{[22]}$ Cevik et al. study that involved 395 elderly trauma patients who were injured in motor vehicle accidents found that median of ISS was 30.5 (range: $|7-4|$ ) and 3 (range: I-9) in non-survivors and survivors, respectively. Mean of RTS was 6.9 (range: 3.98-7.84) and 7.84 (range: 7.84-7.84) in former and latter, respectively. [21] Results indicated that ISS value for survivors is significantly lower than for non-survivors $(p<0.0001)$. Also, RTS $(p<0.000 \mathrm{I})$ and TRISS $(p<0.000 \mathrm{I})$ for survivors were higher than non-survivors. This difference was statistically significant. Akkose's study revealed significant difference between RTS and ISS in both groups. According to their results, mean ISS was lower for survivors, while mean RTS of survivors was higher than that of non-survivors. ${ }^{[22]}$ Area under ROC curve using ISS, RTS, and TRISS for predicting death was $0.76,0.87$, and 0.94 , respectively; all of these scores were statistically significant in terms of mortality prediction. Murlidhar et al. reported that patient mortality rate predicted using TRISS was $10.89 \%$, while rates for RTS and ISS were $61.6 \%$ and $16.6 \%$, respectively, but actual mortality rate was $21.26 \%$. Greater age of patients compared with other studies accounted for this remarkable difference. ${ }^{[28]}$ According to logistic regression model used in our study, TRISS was the strongest predictor of mortality in elderly trauma patients. In a study conducted by Mitchell et al. in Canada published in 2007, it was reported that scoring systems including TRISS had a good ability to predict the prognosis of patients with trauma. ${ }^{[29]}$ In a study conducted in India, Hariharan et al. concluded that using TRISS system to predict morbidity and mortality after fall in the elderly can play an important role in treatment planning. Another study found that TRISS was not very accurate in predicting the prognosis of trauma patients in developing country setting; however, they maintained that TRISS was the most reliable scoring method. ${ }^{[30]}$

\section{Conclusion}

Mortality rate due to trauma in elderly patients is high, and based on our results, TRISS is the most powerful predictor of mortality in these patients, which may be due to consideration of physiological and anatomical parameters. Thus, using TRISS is recommended for proper scoring of trauma severity and predicting mortality in order to implement timely preventive measures and treatments as well as appropriate management of trauma in this age group.

\section{Acknowledgements}

We thank the Clinical Research Development Unit staff of Pour-Sina Hospital and Guilan University of Medical Sciences for their cooperation, and Ms. Fatemeh Javadi for translating the manuscript.

\section{Funding/Support}

None.

Conflict of interest: None declared.

\section{REFERENCES}

1. Adib-Hajbaghery M, Aghahoseini S. The evaluation of disability and its related factors among the elderly population in Kashan, Iran. BMC Public Health 2007;7:261. Crossref

2. Tavakoli H, Ahmadi-Amoli H, Yaghoobi Notash A, Adelyazdankhah Konari A, Gholkhani F, Khashayar P. Trauma-related Mortality and Morbidity due to Trauma in the Elderly. Iranian Journal of Aging 2009;4:30-6.

3. Jacobs DG. Special considerations in geriatric injury. Curr Opin Crit Care 2003;9:535-9. Crossref

4. Parreira JG, Farrath S, Soldá SC, Perlingeiro JA, Assef JC. Comparative analysis of trauma characteristics between elderly and superelderly. Rev Col Bras Cir 2013;40:269-74. Crossref

5. Chu I, Vaca F, Stratton S, Chakravarthy B, Hoonpongsimanont W, Lotfipour S. Geriatric trauma care: challenges facing emergency medical services. Cal J Emerg Med 2007;8:51-5.

6. Callaway DW, Wolfe R. Geriatric trauma. Emerg Med Clin North Am 2007;25:837-60. Crossref

7. Heffernan DS, Thakkar RK, Monaghan SF, Ravindran R, Adams CA Jr, Kozloff MS, et al. Normal presenting vital signs are unreliable in geriatric blunt trauma victims. J Trauma 2010;69:813-20. Crossref

8. Victorino GP, Chong TJ, Pal JD. Trauma in the elderly patient. Arch Surg 2003;138:1093-8. Crossref

9. Aschkenasy MT, Rothenhaus TC. Trauma and falls in the elderly. Emerg Med Clin North Am 2006;24:413-32. Crossref

10. Tajvar M, Arab M, Montazeri A. Determinants of health-related quality of life in elderly in Tehran, Iran. BMC Public Health 2008;8:323:1-8.

11. Mangram AJ, Mitchell CD, Shifflette VK, Lorenzo M, Truitt MS, Goel A, et al. Geriatric trauma service: a one-year experience. J Trauma Acute Care Surg 2012;72:119-22. Crossref

12. Sasser S, Varghese M, Kellermann A, Lormand JD. Prehospital trauma care system. World Health OrganizationGeneva.2005.on May 2015, In: http://www.who.int/violence_injury_prevention/media/ news/04_07_2005/en/, Access on 2015.05.01.

13. MacKenzie EJ, Rivara FP, Jurkovich GJ, Nathens AB, Frey KP, Egleston $\mathrm{BL}$, et al. A national evaluation of the effect of trauma-center care on mortality. N Engl J Med 2006;354:366-78. Crossref

14. Sharma BR. Triage in trauma-care system: a forensic view.J Clin Forensic Med 2005;12:64-73. Crossref

15. Moradi Lakeh M, Tehrani-Banihashemi S.A., Varasteh-Kia G.R, Roohipour M.R. Comparison of Trauma Scoring Systems for Prediction of Patients' Prognosis. RJMS 2002;9:128-9.

16. Chawda MN, Hildebrand F, Pape HC, Giannoudis PV. Predicting outcome after multiple trauma: which scoring system? Injury 2004;35:34758. Crossref

17. Champion HR. Trauma scoring. Scand J Surg 2002;91:12-22.

18. Guzzo JL, Bochicchio GV, Napolitano LM, Malone DL, Meyer W, Scalea TM. Prediction of outcomes in trauma: anatomic or physiologic pa- 
rameters? J Am Coll Surg 2005;201:891-7. Crossref

19. Grinkeviciūte DE, Kevalas R, Saferis V, Matukevicius A, Ragaisis V, Tamasauskas A. Predictive value of scoring system in severe pediatric head injury. Medicina (Kaunas) 2007;43:861-9.

20. Norouzi V, Feizi I, Vatankhah S, Pourshaikhian M. Calculation of the probability of survival for trauma patients based on trauma score and the injury severity score model in fatemi hospital in ardabil. Arch Trauma Res 2013;2:30-5. Crossref

21. Cevik Y, Doğan NÖ, Daş M, Karakayali O, Delice O, Kavalci C. Evaluation of geriatric patients with trauma scores after motor vehicle trauma. Am J Emerg Med 2013;31:1453-6. Crossref

22. Akköse Aydin S, Bulut M, Fedakar R, Ozgürer A, Ozdemir F. Trauma in the elderly patients in Bursa. Ulus Travma Acil Cerrahi Derg 2006;12:230-4.

23. Joseph B, Pandit V, Rhee P, Aziz H, Sadoun M, Wynne J, et al. Predicting hospital discharge disposition in geriatric trauma patients: is frailty the answer? J Trauma Acute Care Surg 2014;76:196-200. Crossref

24. Bradburn E, Rogers FB, Krasne M, Rogers A, Horst MA, Beelen MJ, et al. High-risk geriatric protocol: improving mortality in the elderly. J Trauma Acute Care Surg 2012;73:435-40. Crossref

25. Ferrera PC, Bartfield JM, D’Andrea CC. Outcomes of admitted geriatric trauma victims. Am J Emerg Med 2000;18:575-80. Crossref

26. Richmond TS, Kauder D, Strumpf N, Meredith T. Characteristics and outcomes of serious traumatic injury in older adults. J Am Geriatr Soc 2002;50:215-22. Crossref

27. Kim JK, Choe MS, Lee JH, Park JB, Seo KS, Yun YK. Factors Influencing Mortality in Geriatric Trauma.J Korean Soc Emerg Med 1999;10:421-30.

28. Murlidhar V, Roy N. Measuring trauma outcomes in India: an analysis based on TRISS methodology in a Mumbai university hospital. Injury 2004;35:386-90. Crossref

29. Mitchell AD, Tallon JM, Sealy B. Air versus ground transport of major trauma patients to a tertiary trauma centre: a province-wide comparison using TRISS analysis. Can J Surg 2007;50:129-33.

30. Hariharan S, Chen D, Parker K, Figari A, Lessey G, Absolom D, et al. Evaluation of trauma care applying TRISS methodology in a Caribbean developing country. J Emerg Med 2009;37:85-90. Crossref

\section{ORIJIINAL ÇALIŞMA - ÖZET}

\section{Yaşlı travma hastalarında mortaliteyi öngörmeded gözden geçirilmiş Travma Skoru, Yaralanma Şiddet Skoru ve Travma ve Yaralanma Şiddet Skoru'nun karşılaştırması \\ Dr. Shahrokh Yousefzadeh-Chabok, ${ }^{1,2}$ Dr. Marieh Hosseinpour, ${ }^{1}$ Dr. Leila Kouchakinejad-Eramsadati, ${ }^{1}$ Dr. Fatemeh Ranjbar, ${ }^{2}$ Dr. Reza Malekpouri, ${ }^{1}$ Dr. Alireza Razzaghi, ${ }^{1}$ Dr. Zahra Mohtasham-Amiri ${ }^{1,3}$}

${ }^{1}$ Guilan Road Travma Araştırma Merkezi, Guilan Tıp Bilimleri Üniversitesi, Rasht-Iran

${ }^{2}$ Guilan Tıp Bilimleri Üniversitesi, Nöroşirürji Anabilim Dalı, Rasht-Iran

${ }^{3}$ Sosyal ve Önleyici Tıp Bölümü, Guilan Tıp Bilimleri Üniversitesi, Rasht-Iran

AMAÇ: Altmış beş yaş ve üstü kişilerde travma önde gelen beşinci ölüm nedenidir. Bu çalışma geriyatrik travma olgularında mortaliteyi öngörmede Gözden Geçirilmiş Travma Skoru (RTS), Yaralanma Şiddet Derecesi Skoru (ISS) ve Travma ve Yaralanma Şiddet Skorunu (TRISS) karşılaştırmayı amaçlamıştır.

GEREÇ VE YÖNTEM: 2010 ila 201 I yılları arasında Rasht, Poursina Hastanesi'ne kabul edilmiş 352 yaşlı travma hastasının kayıtlarında yapılmış enine kesit çalışmasıdır. Hastanın prognozuna ilişkin ROC analizini kullanarak yaralanmayı skorlama sistemleri özgüllük, duyarılık ve kesim değerleri açısından karşılaştıııldı.

BULGULAR: Hastalar ortalama 7I.5 yaşındaydı. En sık görülen yaralanma mekanizması trafik kazası olup hastaların \%।3.9'u kaybedilmişti. Sağ kalan yaşlılara göre ölenlerin ISS'si daha yüksek idi. Ölenlere göre yaşlı sağ kalanlarda TRISS ve RTS skorları daha yüksek olup farklılıklar istatistiksel açıdan anlamlı idi $(\mathrm{p}<0.00 \mathrm{I})$. Yaşıı travma hastalarında mortaliteyi öngörmede RTS, ISS ve TRISS skorlama sistemlerinin en iyi kesim değerleri sırasıyla $\leq 6$, $\geq 13,5$ ve $\leq 2$, duyarlılıkları sırasıyla \%99, 84 ve 95 , özgüllükleri ise $\% 62,62$ ve 72 idi.

TARTIŞMA: Hem anatomik hem de fizyolojik parametrelerin kombinasyonu olduğu için mortalitenin en güçlü öngördürücü parametresi TRISS idi. Anahtar sözcükler: Geriyatrik, ROC eğrisi; skorlama; travma.

Ulus Travma Acil Cerrahi Derg 2016;22(6):536-540 doi: 10.5505/tjtes.2016.93288 